\title{
The Expression of Corazonin Neurons in Pupa and Adult Stage of Scuttle Fly
}

\author{
Hohyun Park ${ }^{\dagger ; *}$ \\ Department of Biomedical Laboratory Science, Mokpo Science University, \\ Mokpo-si, Jeollanam-do 58644, Korea
}

\begin{abstract}
The scuttle fly is a fly species in the Phoridae family. Scuttle fly which moves abruptly after standing for a while and stop suddenly to rush off again. These characteristic behaviors of the scuttle fly seem to be related to muscular and nervous system or neurotransmitters. Thus, we focused at the neurotransmitter, corazonin (Crz) that is known to be related to resistance to stress and investigated the developmental process of the neurons in the scuttle fly. In a previous studies, we found that there are three groups of corazoninergic neurons in the larval CNS of the scuttle. Larva has 3 pairs of Crz neurons at the dorsolateral area of the brain, 1 pair at the dorsomedial brain and 8 pairs at the ventral nerve cord. In this studies, among these neurons, 1 pair of dorsomedial brain and 8 pairs of ventral nerve cord disappear in early pupal stage after metamorphosis. Only the 3 pairs of dorsolateral brain persist expression of $\mathrm{Crz}$ gene through all the period of pupa stage. This group of neurons converge gradually to frontal center of the brain and situated at the medial region. These pairs of corazoninergic neurons keep their number and location in adult stage. In the future, we expect further studies on the histological characteristics of corazonin-expressing cells and the expression of corazonin gene.
\end{abstract}

Key Words: Scuttle fly, Corazonin, Central nerve system, Pupa stage, Adult stage

\section{서 론}

곤충이 발생되는 동안 중추신경계에서는 신경팹티드인 corazonin $(\mathrm{Crz})$ 이라는 신경내분비 물질이 분비가 되며, 곤 충류에서 여러 가지 다양한 생리적 기능과 행동 등을 조 절할 수 있는 중요한 역할을 하고 있다고 기존 연구를 통하여 설명을 하였다. Corazonin $(\mathrm{Crz})$ 은 일반적으로 체액 (hemolymph)이 방출되고 있는 곤충의 중추신경계의 측심 체(corpora cardiaca)에서 축삭(axon)을 갖고 있는 전대뇌 (protocelebrum) 부분의 외측부(pars lateralis)쪽에 존재하 고 위치하는 큰 신경내분비세포에 의해 분비 및 생산된 다고 한다(Nässel and Winther, 2010; Altstein and Nassel, 2010).
Corazonin은 세 가지 동형(isoforms)인 [ $\left.\mathrm{Arg}^{7}\right],\left[\mathrm{His}^{7}\right],\left[\mathrm{Thr}^{4}\right.$, $\left.\mathrm{His}^{7}\right]$ corazonin이 곤충에서 확인되었다. [ $\left.\mathrm{Arg}^{7}\right]$ - corazonin 는 초파리(drosophila) (Veenstra, 1994), 나방(moths) (Hansen et al., 2001), 누에(silkworm), 귀뚜라미(crickets), 바퀴벌 레(cockroach) (Hua et al., 2000)에서 보고되었고, [His ${ }^{7}$ corazonin는 메뚜기(locusts)에서 동정이 되었다(Veenstra, 1991; Tawfik et al., 1999). 하지만 $\left[\mathrm{Thr}^{4}, \mathrm{His}^{7}\right]$ 는 최근에 꿀 벌(honey bee)에서 corazonin 유전자로 예측해서 보고가 되 었다(Verleyen et al., 2006; Predel et al., 2007).

신경펩티드 corazonin은 반 생체 안 분석에서 매우 낮 은 농도로 심장박동을 가속시키는 기능이 있었고, 이 결 과로 곤충에서 심장박동을 조절하는 중요한 역할을 한다 고 제안되었다. 하지만, 다른 곤충 및 다른 바퀴벌레종인

Received: November 8, 2021 / Revised: December 13, 2021 / Accepted: December 15, 2021

* Professor.

$\dagger$ Corresponding author: Hohyun Park. Department of Biomedical Laboratory Science, Mokpo Science University, Mokpo-si, Jeollanam-do 58644, Korea. Tel: +82-61-270-2745, Fax:+82-61-270-2745, e-mail:phh7082@hanmail.net

(C) The Korean Society for Biomedical Laboratory Sciences. All rights reserved.

(C) This is an Open Access article distributed under the terms of the Creative Commons Attribution Non-Commercial License (http://creativecommons.org/licenses/by-nc/3.0/) which permits unrestricted non-commercial use, distribution, and reproduction in any medium, provided the original work is properly cited. 
Blattaria 등에서 동일한 결과가 나타나지 않았기 때문에 P. americana에서의 효과만으로는 쉽게 일반화 되면 안 된 다는 것으로 의견이 모아졌다(Predel et al., 1994). 그래서, corazonin에 의한 심장박동 조절은 Periplaneta에서만 유 효한 것으로 결론을 맺었다(Predel et al., 2001).

심장박동을 조절하는 corazonin의 활성은 시험관보다 생체 안에서 보다 많은 활성을 가진다고 하였다. Manduca $\operatorname{sexta}$ 에서 $10^{-7} \mathrm{M}$ 이하의 투여 농도로는 완전한 효과가 없다는 것이 보고되었고, 더 높은 투여 농도(마지막 농 도 $10^{-6} \mathrm{M}$ )로 인해서 즉시 아드레날린과 같은 물질이 증 강되어 순행성 심장박동을 일으켰다(Slama, 2004). 그래 서 corazonin은 잠재적 심장자극 활성물질로 분류되었고 (Slama et al., 2006), 이것은 직접적으로 스트레스 호르몬에 의해 조절된다고 하였다(Nikolarakis et al., 1986; Tellam et al., 1998; Li et al., 2004).

메뚜기에서는 corazonin이 매우 독특한 기능인 군집 상 태를 촉진시키는 호르몬이라고 발표되었다(Tawfik et al., 1999). 군집성의 Locusta migratoria와 Schistocerca gregaria 의 피부에 멜라닌 색소가 비축되었는데, 놀랍게도 이 검정 색소를 유도하는 호르몬이 Periplaneta의 [ $\left.\mathrm{Arg}^{7}\right]$-corazonin 과 비교되는 $\left[\mathrm{His}^{7}\right]$-corazonin과 동형이라는 사실이 밝혀졌 다(Veenstra, 1991; Tawfik et al., 1999).

겉보기에 관련이 없는 기능들이 다양한 곤충 그룹에서 corazonin과 관련이 있는 것으로 보고되었다(Boerjan et al., 2010). P. americana와 대벌레(stick insect)에서 근수축 활동 (Veenstra, 1989; Predel et al., 1999), 메뚜기(locusts \& grasshoppers)에서 큐티클색(Tawfik et al., 1999; Tanaka, 2001; Tanaka et al., 2002a), 촉각감각기(antennal sensilla)의 일부에 서 상 관련된 변화(Maeno \& Tanaka, 2004), 나방(moth)인 Manduca sexta에서 번데기 휴먼 시기의 광 주기 조절과 탈피 행동 유도(Wise et al., 2002; Shiga et al., 2003; Kim et al., 2004; Choi et al., 2005), 누에(silkworm)의 일종인 Bombyx mori의 회전속도 조절(Tanaka et al., 2002b), 가재(crayfish) 피부에서 색소체(chromatophore) 이동, Procambarus clarkii 의 피부에서 외피 색소 이동 등이 그 예이다(Porras et al., 2003). [His ${ }^{7}$-corazonin이 백색소포 색소 과립의 분산과 적 혈구 색소 과립의 수축을 유도한다고 하였다. 그래서 이 것은 색소확산인자(pigment dispersing factor, PDF)에 의해 "밤을 위한 준비" 또는 반대로 "낮을 위한 준비"의 상황을 제공한다고도 비유하였다(Saifullah and Tomioka, 2003). 또 한, 척추동물에서는 홍채(iris)의 활성을 통해 망막(retina)에 도달하는 빛의 양을 조절한다고 하였다(Hoste et al., 2003).
곤충에서 corazonin 뉴런의 발생 과정은 초파리를 포함 한 쌍시류(Diptera) 또는 바퀴벌레, 나방, 딱정벌레 등에서 잘 연구되어 있다. 미국 바퀴벌레에서는 같은 쪽의 측심 체(corpus cardiacum)에서 분비되거나 전대뇌(procerebrum) 측면에서 집합된 열 개의 신경내분비세포에서 corazonin 면역반응이 일어난다고 했다. 고성능액체크로마토그래 피(high-performanced liquid chromatography, HPLC) 분석을 통하여 복부 신경절(abdominal ganglia)과 측심체(corpora cardiaca)에서의 면역양성 물질이 corazonin 이라는 사실 이 확인되었다. 또한 서로 다른 시엽의 뉴런과 중대뇌 (deutocerebrum)와 후대뇌(tritocerebrum)에서 쌍을 이루지 않는 개재뉴런(interneuron)이 식도하신경절(subesophageal ganglion)의 등쪽(dorsal) 중앙에서의 하나의 뉴런과 함께 명확하게 염색이 되었으나, 양성으로 염색된 식도하신경 절은 종 특이적 인공산물일 것이라고 생각하였다(Veenstra and Davis, 1993; Baggerman and Schoofs, 2002). 하지만 메 뚜기 종인 L. migratoria와 S. gregaria의 식도하신경절에 서는 corazonin 뉴런이 나타나지 않는 것을 관찰하였다 (Schoofs et al., 2000).

대표적인 여섯 개 곤충 종류(목)의 중추신경계의 세포 에서 corazonin 뉴런 면역반응이 일어났으며, albino mutant 인 L. migratoria와 딱정벌레(beetle) 둘 다 corazonin 뉴런 이 결여되어 있다는 것을 제외하고는 연구된 모든 곤충 의 복측 신경절(ventral ganglia)과 뇌의 외측부에서 면역반 응 양성 세포의 검출이 보고되었다(Roller et al., 2003).

나방 종인 G. mellonella에서 corazonin 뉴런 유전자가 성 충과 번데기 뿐만 아니라 마지막 령의 애벌레의 뇌의 네 쌍의 측면 신경내분비세포에서 명확하게 발현된다고 보 고되었다(Hansen et al., 2001). 또한, 유사한 뉴런이 오직 M. sexta의 수컷 성충에만 존재한다고 하였다(Lee et al., 2008). Corazonin 신경팹티드의 주된 방출 부위인 측심체 (corpus cardiacum)와 후두 복합체에서 발현되고 서로 다른 측면 반구(hemisphere)와 시엽 부분에 2 5개의 신경 쌍이 corazonin 뉴런 면역반응 발현 부위로 대부분 모든 종에 서 조사했을 때 공통적으로 존재하였다(Predel et al., 2003).

이전 연구에서 scuttle fly의 애벌레 시기를 대상으로 중추신경계에서 발현된 corazonin 뉴런에 대해 관찰을 하 였다. 2령 애벌레 시기에서 중추신경계 조직에 corazonin 을 분비하고 생산하는 뉴런이 큰 범위에서 세 개의 그룹 으로 관찰되었다. 중추신경계 대뇌 조직에서 전대뇌(procerebrum) 양쪽 시엽(optic lobe, OL) 부분에 위치하는 등측 면(dorsolateral, DL) 가장자리 부위에서 세 개의 쌍으로 발 
현되는 corazonin 뉴런들이 강하고 뚜렷하게 관찰되었다. 그리고 대뇌 양쪽 조직 부분에서 맨 중앙 앞쪽과 근접한 부분의 등중앙(dorsomedial, DM) 부위에서도 한 개의 쌍으 로 되어있는 corazonin 뉴런이 더욱 강하게 발현되는 것 을 관찰할 수 있었다. 또한 중추신경계 복신경색 조직 부 분에서는 좌우가 상호 대칭으로 총 여덟 개의 쌍으로 되 어있는 corazonin 뉴런이 강하고 뚜렷하게 발현되는 것을 관찰하였다. 중추신경계의 복신경색 조직에서 발현되는 여덟 개의 쌍으로 이루어진 corazonin 생산 뉴런은 좌측 과 우측의 가장자리에서 대칭으로 발현되었다. 여덟 개의 쌍으로 이루어진 뉴런에서 가장 강하게 발현되는 뉴런이 관찰되었는데, 앞쪽 부분 두 개의 쌍이 뉴런 중에서 가장 강하게 corazonin이 발현이 되는 것을 관찰할 수 있었다. 중추신경계의 복신경색 조직을 측면 쪽에서 관찰했을 때 이 두 개의 쌍으로 구성되어 있는 뉴런은 또 다른 뉴런 들의 쌍 보다 더욱더 등 쪽으로 가까이 위치하고 있는 게 특징이었다. 세 번째 부분의 뉴런 쌍을 포함한 이후의 corazonin 뉴런 쌍들은 거의 동일하게 위치하여 평면 상 으로 좌측과 우측이 서로 대칭으로 위치하고 있었고, 가 장 발현 강도가 낮은 뉴런은 마지막 가장 아래쪽에 있는 쌍에서 관찰되었다. Scuttle fly의 3령 애벌레 시기에서 중 추신경계의 corazonin 분비 뉴런이 발현되는 것과 비교했 을 때 애벌레 2 령 시기와 거의 동일하게 관찰되었다. 하 지만 대뇌 앞쪽의 등쪽 측면(DL) 부분에서의 corazonin 분비 뉴런 보다 대뇌 앞쪽의 등쪽 중앙(DM) 부분에서 한 개의 쌍으로 되어있는 뉴런의 발현이 점점 약해지고 애 벌레 3 령 후기에서 이러한 뉴런의 쌍이 거의 발현이 되 지 않거나 관찰되지 않을 때도 있었다. 중추신경계의 복 신경색 조직에서도 좌측과 우측이 서로 대칭으로 여덟 개의 쌍으로 구성되어 있는 corazonin 뉴런들 중에서 첫 번째와 두 번째 쌍 부분에서 corazonin 분비 뉴런이 강하 고 뚜렷하게 발현되고 있었지만, 세 번째 쌍 부분 부터는 corazonin 분비 뉴런이 점점 아래쪽 끝 부분으로 갈수록 corazonin이 발현되는 정도가 점점 약해지고 있는 특징을 관찰할 수 있었다(Park, 2020).

본 연구에서는 이전 연구의 결과로 얻어진 scuttle fly 애벌레 시기의 중추신경계에서 발현되는 corazonin 뉴런 과 비교하기 위해 번데기와 성충 시기에서 발현된 corazonin 뉴런을 연구하여 이미 연구되어진 동일 초파리 종 인 Drosophila melanogaster와의 결과를 토대로 비교해서 연구해 보고자 한다.
Table 1. Base sequences of primers used for PCR amplification in scuttle fly of corazonin gene

\begin{tabular}{lc}
\hline \hline Name of primers & \multicolumn{1}{c}{ Sequences $\left(5^{\prime} \rightarrow 3^{\prime}\right)$} \\
\hline Scut5'Crz_HindIII & 5'-cgaagcttGAGTCGTATTCCGATATTC \\
Scut3'Crz_XbaI & 5'-ggtctagaCTTCAAATGCGAAACCACA \\
\hline
\end{tabular}

\section{재료 및 방법}

\section{사육}

실험에 이용한 scuttle fly는 Megaselia scalaris라는 학명 을 가진 fly이며, 초파리와 동일한 먹이를 이용하여 사용 하였다. 사육을 위하여 증류수 $250 \mathrm{~mL}$ 에 dextrose $16 \mathrm{~g}$, yeast flakes $6.5 \mathrm{~g}$, cornmeal $20 \mathrm{~g}$, agar $2.25 \mathrm{~g}$ 을 교반기를 이 용하여 혼합하고 전자렌지에서 10 분 정도 끓어 넘치지 않을 정도로 가열하였다. 그리고 methylparaben $6.25 \mathrm{~mL}$ 를 천천히 떨어뜨려서 혼합하고 배지 통에 부은 후 식힌 다 음 성충을 이동시켜 사육을 하였다. 사육은 1 주일 간격으 로 다른 배지에 성충을 옮겨서 지속적으로 시행하였다. 제작된 사육 배지는 $4^{\circ} \mathrm{C}$ 냉장고에 보관하였으며 사용 전 실온에 맞추기 위해 미리 꺼내 놓은 후 사용하였다.

\section{중추신경계 채취}

Scuttle fly을 번데기(pupae) 시기 1 3일, 4 6일, 7 9일, $10 \sim 12$ 일, 13 15일 그리고 성충(adult) 시기별로 각각 5 개 이상의 개체를 사용하였다. $0.1 \%$ tween 20 이 포함되어 있 는 PBS (phosphate buffer solution, $\mathrm{pH}$ 7.0)가 채워져 있는 홈이 파인 슬라이드에 개체를 담근 상태로 실체현미경 (stereomicroscopy) 상에서 가늘고 정밀한 핀셋을 이용하여 번데기, 성충의 껍질 부분을 찣어가면서 채취하였고, 중 추신경계 조직인 대뇌와 복신경색 조직을 적출하여 그 형태를 관찰하였다. 발생 단계별로 채취된 중추신경계 조 직을 $4 \%$ paraformaldehyde 용액에 넣은 후 $4{ }^{\circ} \mathrm{C}$ 냉장고에 1 시간 이상 고정하여 보관하였다.

\section{Probe 제작}

제자리혼성화법(ISH)으로 corazonin을 검출하기 위해 RNA probe를 제작하였다. 먼저 scuttle fly의 DNA를 phenol /chloroform 법으로 추출하였다. Primer는 corazonin gene의 특이한 염기서열을 선택하고 primer의 앞 부분에는 subcloning에 필요한 제한효소 부위를 추가하여 주문 제작하 여 PCR을 시행하였다(Table 1). PCR의 조성은 $10 \mathrm{X}$ PCR 


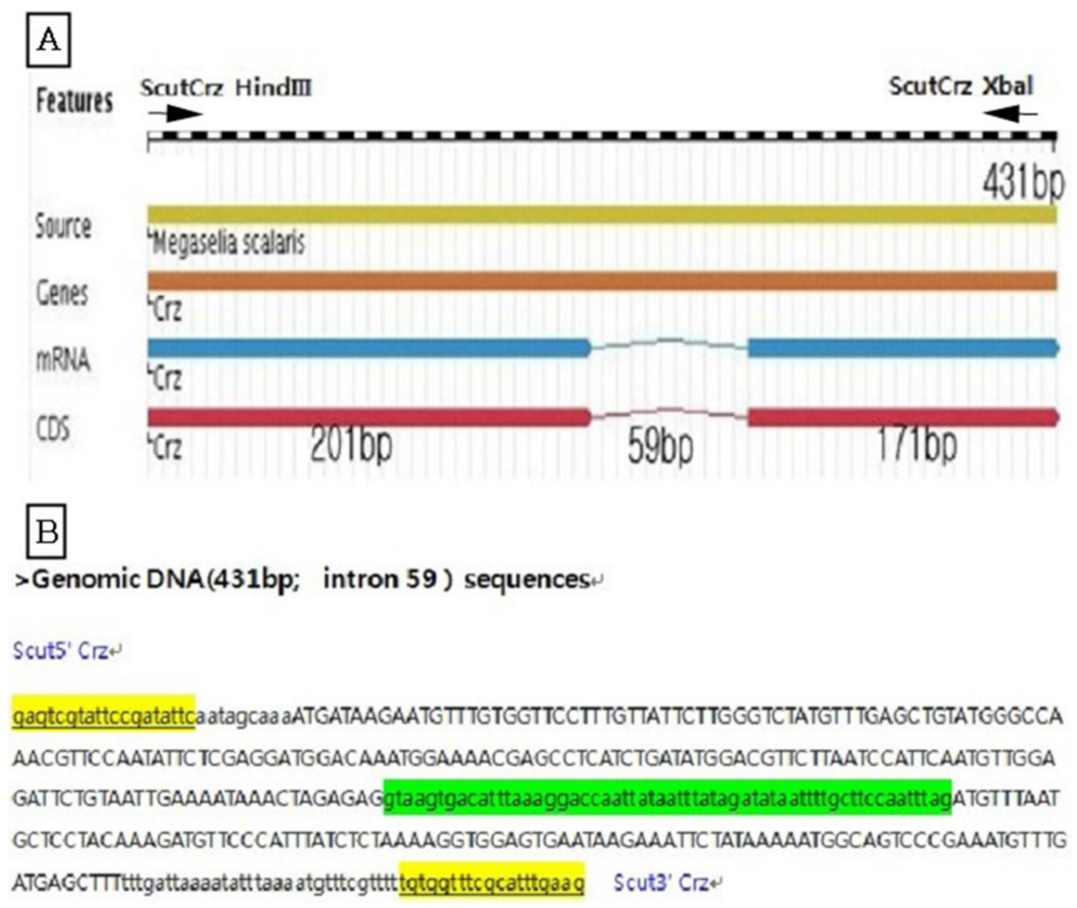

Fig. 1. Structure of $\mathrm{Crz}$ gene in scuttle fly. A; map for the $\mathrm{Crz}$ coding region. B; sequences of the genomic Crz gene. The coding sequences are shown in capital letters and 5'-UT, intron, 3'-UT sequences are shown in lower case. buffer $2 \mu \mathrm{L}, 10 \mathrm{mM}$ Scutt 5' Crz HindIII primer $1 \mu \mathrm{L}, 10 \mathrm{mM}$ Scutt 3' Crz XbaI primer $1 \mu \mathrm{L}$ (Kim et al., 2013; Genbank KF318884.1), $2.5 \mathrm{mM}$ dNTP $1.6 \mu \mathrm{L}$, DNA Taq polymerase 1 unit (Elpis, Korea), template DNA 1 10 ng, 그리고 증류수 를 추가하여 최종 부피 $20 \mu \mathrm{L}$ 가 되도록 하였다(Fig. 1). $\mathrm{PCR}$ 은 전변성(pre-denature) $94^{\circ} \mathrm{C} 2$ 분, 변성(denature) $94^{\circ} \mathrm{C}$ 1 분, 결합(annealing) $56^{\circ} \mathrm{C} 1$ 분, 신장(extension) $72^{\circ} \mathrm{C} 1$ 분 과 정을 30 회 반복 수행하고 후신장(post-extension)은 $72^{\circ} \mathrm{C}$ 에서 5 분간 진행하였다. $\mathrm{PCR}$ 증폭 산물은 $\mathrm{EtBr}$ (ethidium bromide)로 염색한 후 $1.6 \%$ agarose gel에서 전기영동(RunOne Electrophoresis Cell, Embi Tec, USA) 하여 UV transilluminator 상에서 밴드를 확인하였다.

증폭 PCR 산물을 pGEM-T Easy vector (Promega Corporation, Madison, WI, USA)에 삽입하여 T7 프로모터를 연결 하였다. 이 백터를 주형으로 in vitro transcription을 시행하 여 RNA 탐침을 만들었다. Digoxygenin으로 표지된 탐침 을 만들기 위해 10X T7 RNA polymerase buffer $2 \mu \mathrm{L}, 50 \mathrm{mM}$ DTT $2 \mu \mathrm{L}, 20 \mathrm{mM}$ 의 NTP mixture $1 \mu \mathrm{L}, 10 \mathrm{mM}$ Dig-11-UTP $1 \mu \mathrm{L}$, RNase inhibitor 20 unit, template DNA $20 \sim 1 \mu \mathrm{g}, \mathrm{T} 7$ RNA polymerase 50 unit, 그리고 RNase free 증류수를 넣어 최종 부피 $20 \mu \mathrm{L}$ 를 만들어 $42{ }^{\circ} \mathrm{C}$ 에서 2 시간 반응하고 $1.6 \%$ agarose gel에 전기영동 하여 Dig labeling의 여부를 확인하 였다.
제작된 corazonin RNA Dig-probe의 조직 침투 효율성 을 높이기 위해서 fragmentation 과정을 실시하였다. 먼저 Dig-labeling 된 in vitro transcription 산물에 $2 \mu \mathrm{L}$ 의 DNase $\mathrm{I}$ 을 넣고 $37^{\circ} \mathrm{C}$ 에서 15 분간 incubation 하여 주형 $\mathrm{DNA}$ 를 절단하고 $\mathrm{DNase} I$ 의 활성을 멈추기 위하여 $0.2 \mathrm{M} \mathrm{EDTA}$ (RNase free) $2 \mu \mathrm{L}$ 를 넣었다.

그 다음으로 nucleotide 조각을 제거하고 RNA의 농축 을 위해서 0.1 volume의 $5 \mathrm{M} \mathrm{LiCl}$ 와 2.5 volume의 $100 \%$ Ethanol을 넣고 $-70^{\circ} \mathrm{C}$ 에서 30 분간 침전 후 $4{ }^{\circ} \mathrm{C}$ 에서 15 분 간 $12,000 \mathrm{~g}$ 로 원심분리 하고 $70 \%$ ethanol를 이용하여 수 세를 실시하였다. 침전된 RNA는 5 분 동안 공기 중 상태 에서 말린 후 hydrolysis buffer $(40 \mathrm{mM} \mathrm{NaHCO} / 60 \mathrm{mM}$ $\mathrm{Na}_{2} \mathrm{CO}_{3}, \mathrm{pH}$ 9.2 10.2)에 넣고 $60^{\circ} \mathrm{C}$ 에서 10 분간 fragmentation을 실시하였다. 마지막으로 $10 \mu \mathrm{L}$ 의 $1 \mathrm{M}$ Tris $(\mathrm{pH}$ 7.5), $300 \mu \mathrm{L}$ 의 in situ hybrix buffer, 그리고 $1 \mu \mathrm{L}$ 의 RNase inhibitor를 넣고 $-20^{\circ} \mathrm{C}$ 보관하여 사용하였다.

\section{제자리혼성화(ISH) 방법}

4\% paraformaldehyde 용액에 고정된 중추신경계 조직을 먼저 PBTw (0.1\% tween 20 in phosphate buffer solution, $\mathrm{pH}$ 7.0)로 충분히 수세하여 고정액을 완전히 제거하였다. 고 정액이 제거된 다음 평형 형성(equilibration)을 시키기 위 해 실온에서 $\mathrm{PBTw}$ : hybrix $(1: 1)$ 로 반응시킨 다음 $60^{\circ} \mathrm{C}$ 에 


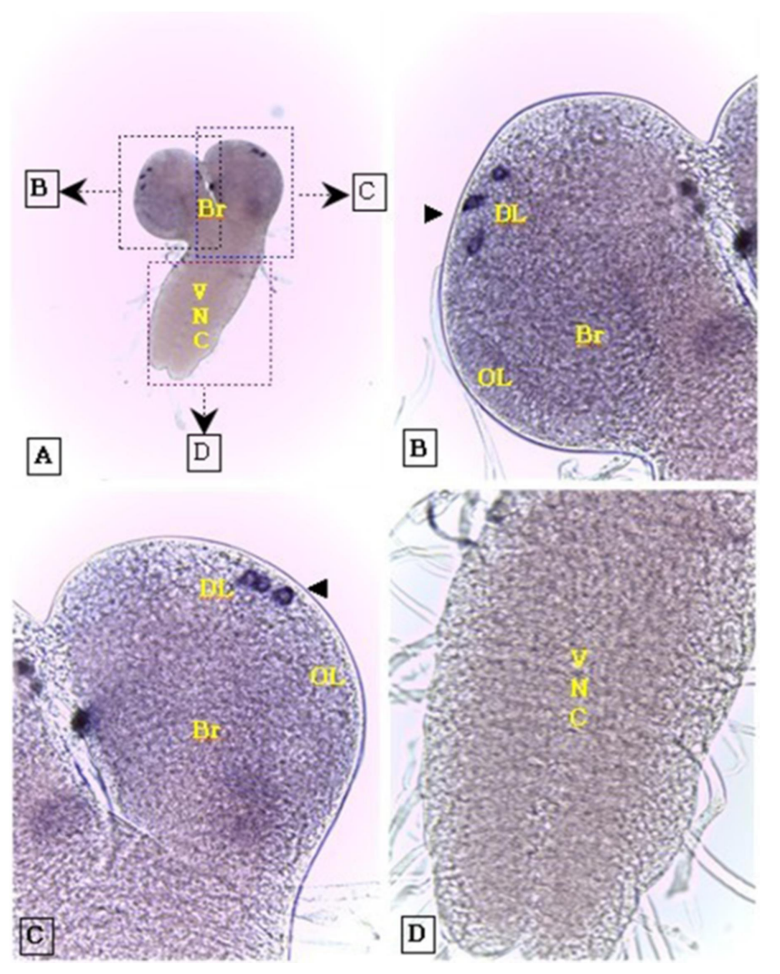

Fig. 2. Identification of corazoninergic neurons in CNS of scuttle fly pupa at $1 \sim 3$ days period by in situ hybridization. A; whole sample $(\times 100)$. B, C, D; partial enlargement of CNS $(\times 400)$. Br; brain, DL; dorsolateral, DM; dorsomedial, VNC; ventral nerve cord, OL; optic lobe.

서 3 4시간 정도 hybrix 용액 $(50 \%$ deionised formamide $50 \mathrm{~mL}, 5 X$ SSC $25 \mathrm{~mL}, 100 \mu \mathrm{g} / \mathrm{mL}$ tRNA $0.5 \mathrm{~mL}, 100 \mu \mathrm{g} / \mathrm{mL}$ ssDNA $1 \mathrm{~mL}, 50 \mu \mathrm{g} / \mathrm{mL}$ Heparin $45 \mu \mathrm{L}, 0.1 \%$ Tween- $20,1 \mathrm{~mL}$, $\mathrm{dH}_{2} \mathrm{O} 22.5 \mathrm{~mL}$ )에 전혼성화(prehybridization) 시켰다.

전혼성화가 끝나기 전에 미리 탐침(probe)을 $100^{\circ} \mathrm{C}$ 에서 10 분 정도 변성(denature)시킨 후 바로 얼음물에 3 분 이상 담가서 다시 회복되지 못하게 하고 $60^{\circ} \mathrm{C}$ 에 반응시킨 전 혼성화 용기에 탐침(probe)를 혼합하여 12 14시간 정도 반응시켜 혼성화(hybridization) 시켰다. 혼성화가 끝나면 hybrix와 PBTw의 비율을 tube에 5:0, 4:1, 3:2, 2:3, 1:4, 0:5로 미리 만들어 $60^{\circ} \mathrm{C}$ 로 담가둔 후 단계별로 10 분 동안 $60^{\circ} \mathrm{C}$ 온도 상태에서 반응을 시킨 후, 실온에서 $\mathrm{PBTw}$ 로 깨끗이 다시 한번 수세를 하였다. 비특이적인 반응을 차단하기 위하여 정상 동물 혈청인 BSA (bovine serum albumin)와 NSS (normal sheep serum)를 PBTw에 일정량을 희석하여 2시간 동안 blocking 단계를 시행하였고, 반응이 끝난 후 blocking 시약을 제거한 후 PBTw에 항체(anti-digoxigeninAP Fab fragments, Roche Diagnostic, Germany)를 1:000으로
희석하여 2 시간 동안 반응시켰다.

항체반응이 끝난 후 $\mathrm{PBTw}$ 에 여러 번 수세하고 검출 완충액(detection buffer, pH 9.5)를 반응 시킨 후 alkaline phosphate (AP) 기질(substrate)인 NBT/BCIP 저장 용액 (Roche Diagnostics, Germany)과 검출 완충액을 1:100 희석 하여 20 분 간격으로 발색되는 것을 실체현미경으로 관찰 하였고, 발색이 완료되었을 때 PBTw으로 반응을 정지시 키고 철저하게 수세를 하였다.

제자리혼성화법이 완료된 중추신경계의 조직은 glycerin 을 $\mathrm{PBTw}$ 에 각각 $50 \%, 70 \%$ 농도 단계를 거쳐서 중추신 경계 조직을 올바른 방향으로 슬라이드에 위치시킨 후 cover glass로 봉입한 후 광학현미경(light microscopy, LEICA ICC50 HD, Germany) 상에서 관찰하여 사진을 촬영하였다.

\section{결 과}

번데기(pupae) 시기에서 중추신경계 조직의 corazonin 생산 뉴런의 발달은 애벌레에서 번데기로 변태가 이루어 지면서, 중추신경계 조직에서 corazonin 뉴런은 두 개의 그룹이 사라지고 한 개의 그룹에서만 계속해서 corazonin 을 발현하였다. 애벌레 시기에서 corazonin을 발현하던 전 대뇌 등중앙 $(\mathrm{DM})$ 양쪽 한 쌍과 복신경색에 존재하는 여 덟 쌍의 corazonin 뉴런이 번데기로 변태가 이루어짐과 동시에 사라져 버리는 것을 볼 수 있었다. 반면 시엽 근 처의 전대뇌 등측면(DL) 부분에 corazonin 뉴런 세 쌍은 여전히 뚜렷하게 corazonin을 발현하고 있었다(Fig. 2). 이 세 쌍의 corazonin 뉴런은 번데기 시기 내내 그 발현 양 상을 유지하였으며 시엽이 발달할수록 중앙으로 수렴되 어 번데기 말기에는 거의 중앙 부위에 위치하였다. 사라 진 등중앙 $(\mathrm{DM})$ 뉴런 쌍과 복신경색의 뉴런 여덟 쌍은 번데기 시기의 어느 단계에서도 다시 나타나지 않았다 (Fig. 3-6).

성충(adult fly) 시기에서 중추신경계 조직의 corazonin 생산 뉴런의 발달은 대뇌 중앙으로 이동한 세 쌍의 등측 면(DL) corazonin 뉴런들은 성체에서 거의 정중앙에 좌우 로 배치되었다(Fig. 7A, B). 하지만 성충 시기의 중추신경 계에서의 발현된 corazonin 뉴런을 살펴보았을 때, 대뇌 조직의 등측면(DL)에서 발현된 corazonin 뉴런 세 쌍이 전대뇌 앞쪽 중앙 뇌간부 (pars intercerebralis)에 집합되어 존재하는 것을 관찰할 수 있었다(Fig. $7 \mathrm{C}, \mathrm{D})$. 그리고 번데 기 시기와 마찬가지로 애벌레 시기에 corazonin 뉴런이 발현되었던 전대뇌 등중앙(DM) 양쪽 가장자리 부분의 한 

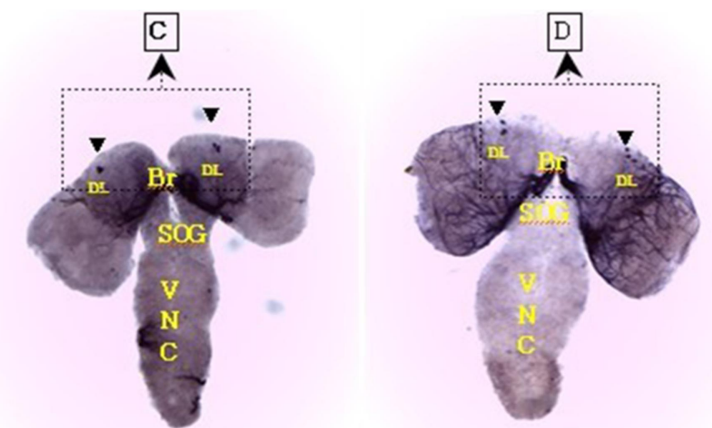

A

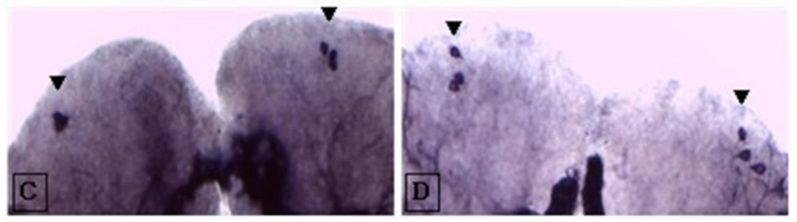

Fig. 3. Identification of corazoninergic neurons in CNS of scuttle fly pupa at $4 \sim 6$ days period by in situ hybridization. A, B; whole sample $(\times 100)$. C, D; partial enlargement of CNS $(\times 400)$. Br; brain, DL; dorsolateral, VNC; ventral nerve cord, OL; optic lobe, SOG; subesophagus ganglion.

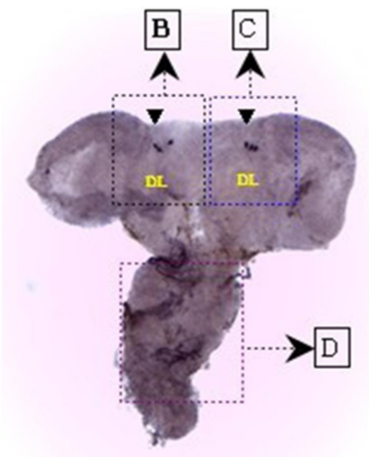

A
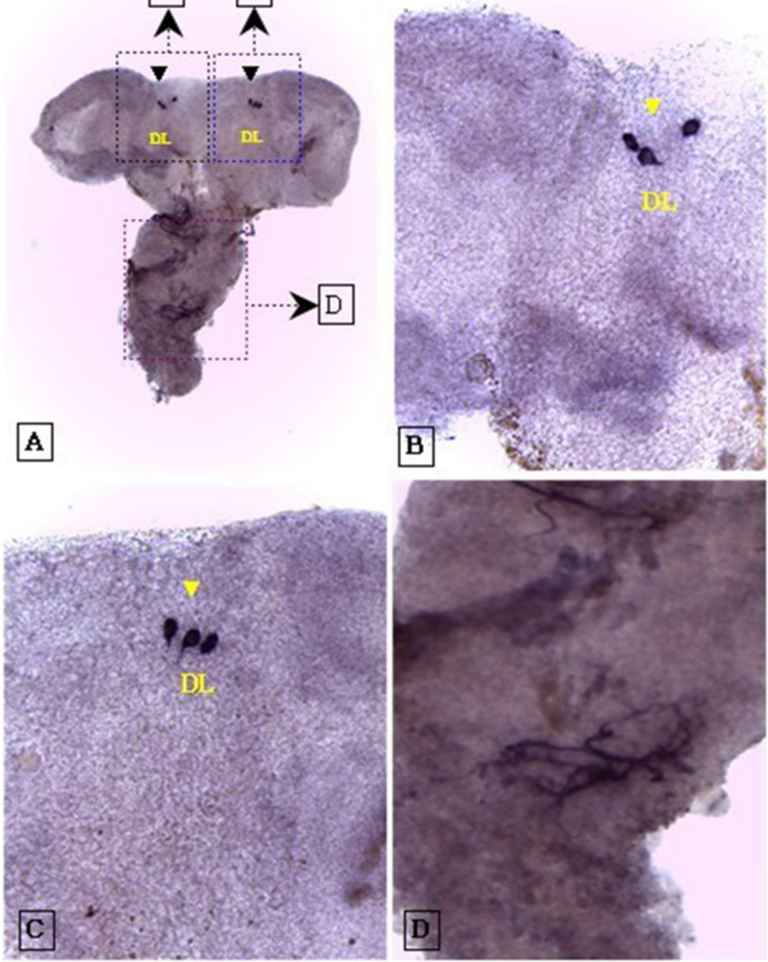

Fig. 4. Identification of corazoninergic neurons in CNS of scuttle fly pupa at 7 $\sim 9$ days period by in situ hybridization. A; whole sample $(\times 100)$. B, C, D; partial enlargement of CNS $(\times 400)$. DL; dorsolateral.

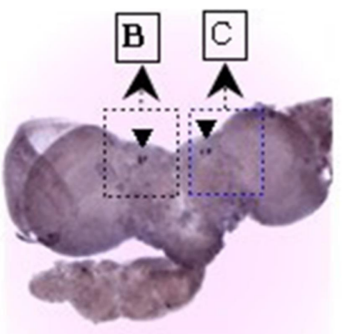

A

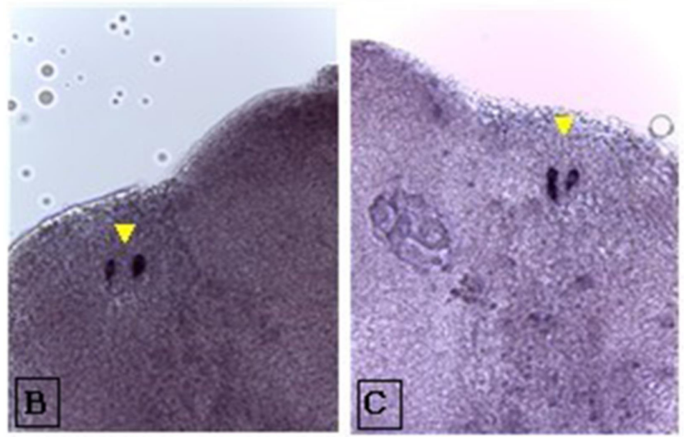

Fig. 5. Identification of corazoninergic neurons in CNS of scuttle fly pupa at $10 \sim 12$ days period by in situ hybridization. A; whole sample $(\times 100)$. B, C; partial enlargement of CNS $(\times 400)$.

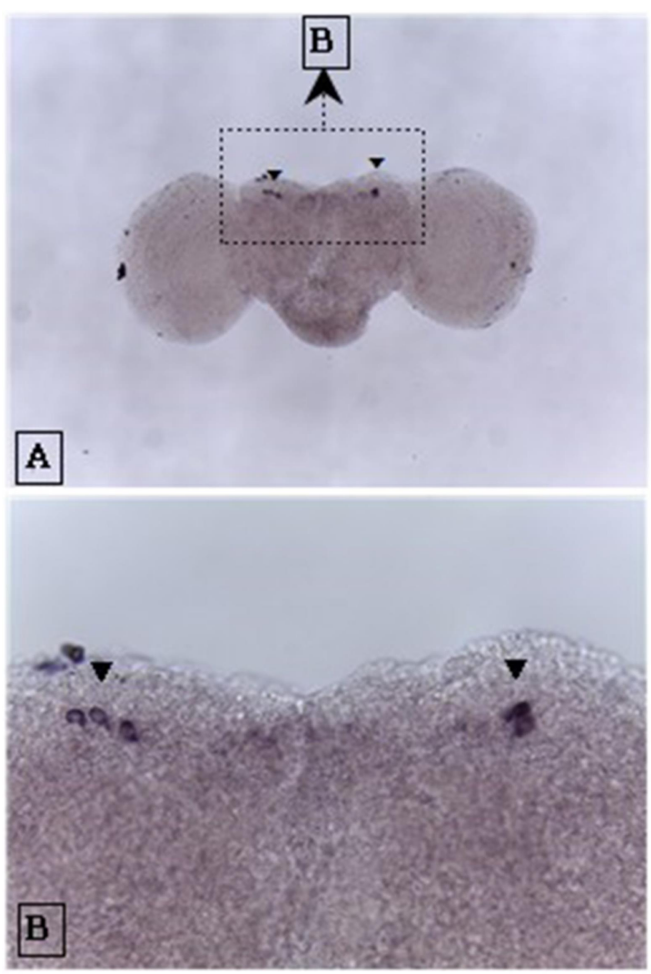

Fig. 6. Identification of corazoninergic neurons in CNS of scuttle fly pupa at $13 \sim 15$ days period by in situ hybridization. A; whole sample $(\times 100)$. B; partial enlargement of CNS $(\times 400)$. 


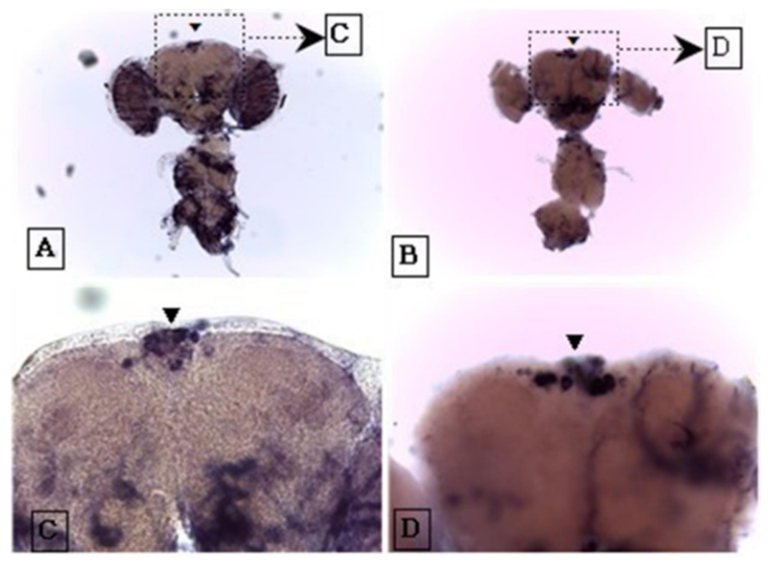

Fig. 7. Identification of corazoninergic neurons in CNS of scuttle fly adult period by in situ hybridization. A, B; whole sample $(\times 100)$. $\mathrm{C}$, D; partial enlargement of CNS $(\times 400)$.

쌍과 복신경색의 여덟 쌍이 존재하지 않는 것도 확인하 였다. 애벌레나 번데기 시기에 비해서 중추신경계 조직에 신경섬유가 많이 증가되어 있어서 배경은 깨끗하지는 않 았다(Fig. 7).

초파리와는 달리 성체의 뇌에서 corazonin 뉴런의 수는 더 이상 늘어나지 않았다. 처음부터 corazonin을 생산하던 세 쌍의 뉴런들만이 성체에서도 corazonin을 발현하면서 그 기능을 유지하였다(Fig. 7).

\section{고 찰}

Scuttle fly의 애벌레 2, 3령 시기에서 중추신경계 대뇌 조직과 복신경색 조직을 채집해서 제자리혼성화(ISH) 검 사 방법을 통하여 corazonin 분비 뉴런 유전자의 발현 유 무 정도를 관찰하여 확인하였다. Corazonin 뉴런은 애벌레 2,3 령 시기의 중추신경계 대뇌 조직에서 등쪽 중앙(DM) 한 개의 쌍, 등쪽 측면(DL) 세 개의 쌍, 복부신경색 조직 에서 좌측과 우측 대칭인 여덟 개의 쌍으로 존재하는 것 을 관찰함으로써, 중추신경계에서 corazonin을 분비하는 뉴런이 대뇌와 복신경색 조직에서 크게 세 개의 그룹에 서 발현되고 있는 것을 확인하였다(Park, 2020). 하지만 애 벌레에서 번데기로 변태가 되는 동안에, corazonin 발현 패턴에 크게 변화가 이루어진다.

D. melanogaster의 애벌레 시기에 복부신경색(VNC)의 여덟 쌍으로 되어 있는 corazonin 발현 뉴런이 초기 번데 기로 변태되는 동안에 제거가 되었고, 이것은 번데기 형 성 후 $0 \sim 3$ 시간 동안 복신경색(VNC)에 유지가 되고 있지
만 4 6시간이 되면 없어지기 시작하여 7시간 정도가 되 면 완전히 소실된다고 하였다. 또한 후기 번데기 발생 동 안에 대뇌 앞쪽(protocerebrum)에서 전두엽(frontal lobe)의 등쪽 중앙 $(\mathrm{DM})$ 쪽에 위치해서 발현되는 corazonin 뉴런의 한 개의 쌍이 제거가 된다고 하였다. 그리고 대뇌에 존재 하는 등쪽 측면(DL)쪽에서 발현되는 세 개의 쌍으로 구 성되어 있는 corazonin 뉴런은 성충 시기에도 지속적으로 같은 위치에 존재하고 있으면서 새로운 신생 corazonin 뉴런과 집합되어 존재한다고 보고되었다(Choi et al., 2005; Choi et al., 2006; Choi, 2009; Lee et al., 2008; Lee et al., 2011).

Scuttle fly에서도 D. melanogaster와 마찬가지로 애벌레가 번데기로 변태하는 동안에 번데기가 시작되는 시점부터 바로 복신경색 조직에서 발현되는 여덟 쌍의 corazonin 뉴런이 발현되지 않는 것을 확인하였다. 하지만 전두엽의 등중앙(dorsomedial, DM)에 존재하는 corazonin 발현 뉴런 한 쌍이 D. melanogaster와 다르게 번데기가 발생하자마자 복신경색 조직과 함께 제거가 되어 없어진다는 것을 알 아냈다.

한편, scuttle fly에서 전대뇌 양쪽 등측면(DL) 부분에서 세 쌍의 발현되는 corazonin 뉴런은 D. melanogaster와 같 이 애벌레에서 성충 시기까지 지속적으로 존재하는 것을 확인하였다. 그러나 D. melanogaster에서와 달리 scuttle fly에서는 corazonin 발현 뉴런이 애벌레부터 번데기 시기 까지 전대뇌 부분의 시엽쪽(optic lobe) 가장자리인 등측면 (DL)에 위치해 있다가 점점 대뇌 앞쪽 중앙 부분으로 이 동하는 특징을 확인하였고, 성충 시기가 되면서 대뇌 조 직의 좌측과 우측 등측면(DL)에서 발현된 세 쌍의 corazonin 뉴런이 대뇌 앞쪽 중앙 부분에 집합되어 발현되는 것을 알아냈다.

Scuttle fly를 비롯해서 특히 완전변태의 곤충에서 중추 신경계(CNS)의 수많은 뉴런과 함께 대부분의 애벌레 조 직은 세포의 죽음 프로그램(programmed cell death, $\mathrm{PCD}$ )에 의해 제거되는 동안 극적으로 성충 특정 조직과 뉴런에 의해 신생된 조직과 신경세포를 새로이 형성하게 된다고 보고되었다(Riddiford, 1993; Truman et al., 1993; Truman et al., 1994). 이러한 발생학적인 현상에 의해서 조직이 세포 분열 하여 새로이 만들어지거나 또는 생리적인 현상에 의해 세포자연사에 의해서 없어지기도 한다고 하였다. 이 러한 현상은 발생학적으로 조절하는 어떠한 물질들이 활 성화 되거나 억제되면서 이루어진다고 보고가 있었다(Shi, 2002; Hay and Guo, 2006). 그래서 corazonin 발현 뉴런이 극적인 발생 과정 중에서 제거가 되고 생성이 되는 것은 
세포자연사에 의한 생리적인 현상이라고 추측할 수 있 었다.

\section{ACKNOWLEDGEMENT}

This study was supported by reserch fund Mokpo Science University, 2021.

\section{CONFLICT OF INTEREST}

The authors affirm that they have no academic, financial or rights interests.

\section{REFERENCES}

Altstein M, Nassel DR. Neuropeptide signaling in insects. In: Geary, T. G., Maule, A. G. (Eds.), Neuropeptide Systems as Targets for Parasite and Pest Control. 2010. pp. 155-165.

Baggerman G, Schoofs L. The use of mass spectrometry and capillary chromatography in the identification and quantification of neuropeptides in insects. Ph.D. Thesis, KU. Leuven. 2002. pp. 44.

Boerjan B, Verleyen P, Huybrechts J, Schoofs L, De Loof A. In search for a common denominator for the diverse functions of arthropod corazonin; a role in the physiology of stress? Gen Comp Endocrinol. 2010. 166: 222-233.

Choi SH. "The Regulation of Neuropeptide Corazonin and Its Functional Analyses in Drosophila melanogaster." $\mathrm{PhD}$ diss., University of Tennessee. 2009.

Choi YJ, Lee G, Park JH. Programmed cell death mechanisms of identifiable peptidergic neurons in Drosophila melanogaster. Development. 2006. 133: 2223-2232.

Choi YJ, Lee G, Hall JC, Park JH. Comparative analysis of Corazonin-encoding genes (Crz's) in Drosophila species and functional insights into Crz-expressing neurons. J Comp Neurol. 2005. 482: 372-385.

Hansen IA, Sehnal F, Meyer SR, Scheller K. Corazonin gene expression in the waxmoth Galleria mellonella. Insect Mol Biol. 2001. 10: 341-346.

Hay BA, Guo M. Caspase-dependent cell death in Drosophila. Annu Rev Cell Dev Biol. 2006. 22: 623-650.

Hoste B, Simpson SJ, De Loof A, Breuer M. Behavioral differences in Locusta migratoria associated with albinism and their relation to [His(7)]-corazonin. Physiol Entomol. 2003. 28: 3238.

Hua YJ, Ishibashi J, Saito H, Tawfik A, Sakakibara M, Tanaka Y,
Derua R, Waelkens E, Baggerman G, De Loof A, Schoofs L, Tanaka S. Identification of [Arg7] corazonin in the silkworm, Bombyx mori and the cricket, Gryllus bimaculatus, as a factor inducing dark color in an albino strain of the locust, Locusta migratoria. J Insect Physiol. 2000. 46: 853-860.

Kim J, Kim JW, Park JH. Characterization and expression of corazonin gene in the scuttle fly, Megaselia scalaris. 2013. GenBank; KF318884.1

Kim YJ, Spalovska-Valachova I, Cho KH, Zitnanova I, Park Y. Corazonin receptor signaling in ecdysis initiation. Proc Natl Acad Sci U S A. 2004. 101: 6704-6709.

Lee G, Kim KM, Kikuno K, Wang Z, Choi YJ, Park JH. Developmental regulation and functions of the expression of the neuropeptide corazonin in Drosophila melanogaster. Cell Tissue Res. 2008. 331: 659-673.

Lee G, Wang Z, Sehgal R, Chen CH, Kikuno K, Hay B, Park JH. Drosophila caspases involved in developmentally regulated programmed cell death of peptidergic neurons during early metamorphosis. J Comp Neurol. 2011. 519: 34-48.

Li XF, Bowe JE, Mitchell JC, Brain SD, Lightman SL, O'Byrne KT. Stress-induced suppression of the gonadotropin-releasing hormone pulse generator in the female rat: a novel neural action for calcitonin gene-related peptide. Endocrinology. 2004. 145: 1556-1563.

Maeno K, Tanaka S. Hormonal control of phase-related changes in the number of antennal sensilla in the desert locust, Schistocerca gregaria: possible involvement of [His7]-corazonin. J Insect Physiol. 2004. 50: 855-865.

Nässel DR, Winther AM. Drosophila neuropeptides in regulation of physiology and behavior. Prog Neurobiol. 2010. 92: 42-104.

Nikolarakis KE, Almeida OF, Herz A. Corticotropin-releasing factor $(\mathrm{CRF})$ inhibits gonadotropin-releasing hormone $(\mathrm{GnRH})$ release from superfused rat hypothalami in vitro. Brain Res. 1986. 377: 388-390.

Park HH. The Expression of Corazonin Neurons in Larvae Stage of Scuttle Fly. Biomedical Laboratory Sciences. 2020. 26: 1-9.

Porras MG, De Loof A, Breuer M, Arechiga H. Corazonin promotes tegumentary pigment migration in the crayfish Procambarus clarkii. Peptides. 2003. 24: 1581-1589.

Predel R, Agricola H, Linde D, Wollweber L, Veenstra JA, Penzlin $H$. The insect neuropeptide corazonin: physiological and immunocytochemical studies in Blattariae. Zoology (ZACS). 1994. 98: 35-49.

Predel R, Herbert Z, Eckert M. Neuropeptides in perisympathetic organs of Manduca sexta; specific composition and changes 
during development. Peptides. 2003. 24: 1457-1464.

Predel R, Kellner R, Gade G. Myotropic neuropiptides from the retrocerebral complex of the stick insect, Carausius morosus (Phasmatodea: Lonchodidae). Eur. J. Entomol. 1999. 96: 275278.

Predel R, Nachman RJ, Gade G. Myostimulatory neuropeptides in cockroaches: structures, distribution, pharmacological activities, and mimetic analogs. J Insect Physiol. 2001. 47: 311-324.

Predel R, Neupert S, Russell WK, Scheibner O, Nachman RJ. Corazonin in insects. Peptides. 2007. 28: 3-10.

Riddiford LM. Hormones and Drosophila development. In: Bate M, Arias A. M, editors. The development of Drosophila melanogaster. Cold Spring Harbor, NY: Cold Spring Harbor Press. 1993. p 899-939.

Roller L, Tanaka Y, Tanaka S. Corazonin and corazonin-like substances in the central nervous system of the Pterygote and Apterygote insects. Cell Tissue Tes. 2003. 312: 393-406.

Saifullah ASM, Tomioka K. Pigment-dispersing factor sets the night state of the medulla bilateral neurons in the potic lobe of the cricket, Gryllus bimaculatus. J Insect Physiol. 2003. 49: 231-239.

Schoofs L, Baggerman G, Veelaert D, Breuer M, Tanaka S, De Loof A. The pigmentotropic hormone [His7]-corazonin, absent in a Locusta igratoria albino strain, occurs in an albino strain of Schistocerca gregaria. Mol Cell Endocrinol. 2000. 168: 101-109.

Shiga S, Davis NT, Hildebrand JG. Role of neurosecretory cells in the photoperiodic induction of pupal diapause of the tobacco hornworm Manduca sexta. J Comp Neurol. 2003. 462: 275-285.

Shi Y. Mechanisms of caspase activation and inhibition during apoptosis. Mol Cell. 2002. 9: 459-470.

Slama K. The effect of corazonin on heartbeat reversal in pupae of the tobacco hornworm, Manduca sexta (Lepidoptera: Sphingidae). Eur J Entomol. 2004. 101: 513-521.

Slama K, Sakai T, Takeda M. Effect of corazonin and cardioactive peptide on heartbeat in the adult American cockroach (Periplaneta americana). Arch Insect Biochem Physiol. 2006. 62: 91-103.

Tanaka S. Endocrine mechanism of controlling body-color poly morphism in locusts. Arch Insect Biochem Physiol. 2001. 47: 139-149.

Tanaka S, Zhu DH, Hoste B, Breuer M. The dark-color inducing neuropoptide, His7-corazonin, causes a shift in morphometric characteristics towards the gregarious phase in isolated-reared (solitarious) Locusta migratoria. J Insect Physiol. 2002a. 48:
1065-1074

Tanaka Y, Hua Y, Roller L, Tanaka S. Corazonin reduces the spinning rate in the silk worm, Bombyx mori. J Insect Physiol. 2002b. 48: 707-714.

Tawfik AI, Tanaka S, De Loof A, Schoofs L, Baggerman G, Waelkens E, Derua R, Milner Y, Yerushalmi Y, Pener MP Identification of the gregarization - associated dark - pigmentotropin in locusts through an albino mutant. Proc Natl Acad Sci U S A. 1999. 96: 7083-7087.

Tellam DJ, Perone MJ, Dunn IC, Radovick S, Brennand J, Rivier JE, Castro MG, Lovejoy DA. Direct regulation of GnRH transcription by CRF-like peptides in an immortalized neuronal cell line. Neuroreport. 1998. 9: 3135-3140.

Truman JW, Talbot WS, Fahrbach SE, Hogness DS. Ecdysone receptor expression in the CNS correlates with stage-specific responses to ecdysteroids during Drosophila and Manduca development. Development. 1994. 120: 219-234.

Truman JW, Taylor BJ, Awad TA. Formation of the adult nervous system. In: Bate, M., Arias A. M., editors. The development of Drosophila melanogaster. Cold Spring Harbor, NY: Cold Spring Harbor Press. 1993. p 1245-1275.

Veenstra JA. Isolation and structure of corazonin, a cardio-active peptide from the America cockroach. FEBS Lett. 1989. 250 231-234.

Veenstra JA. Presence of corazonin in three insect species, and isolation and identification of [His7] corazonin from Schistocerca americana. Peptides. 1991. 12: 1285-1289.

Veenstra JA. Isolation and structure of the Drosophila corazonin gene. Biochem. Biophys Res Commun. 1994. 204: 292-296.

Veenstra JA, Davis NT. Localization of corazonin in the nervous system of the cockroach Periplaneta americana. Cell Tissue Res. 1993. 274: 57-64.

Verleyen P, Baggerman G, Mertens I, Vandersmissen T, Huybrechts J, Van Lommel A, De Loof A, Schoofs L. Cloning and characterization of a third isoform of corazonin in the honey bee Apis mellifera. Peptides. 2006. 27: 493-499.

Wise S, Davis NT, Tyndale E, Noveral J, Folwell MG. Neuroanatomical studies of period gene expression in the hawkmoth, Manduca sexta. J Comp Neurol. 2002. 447: 366-380.

https://doi.org/10.15616/BSL.2021.27.4.239

Cite this article as: Park $\mathrm{H}$. The Expression of Corazonin Neurons in Pupa and Adult Stage of Scuttle Fly. Biomedical Science Letters. 2021. 27: 239-247. 